\title{
Conceptions of health education practices in the context of Nursing Education
}

\author{
Concepções das práticas de educação em saúde no contexto da formação em Enfermagem
}

Sâmia Jucá Pinheiro ${ }^{1}$,Francisca Ediquelle Queiroz Lucas ${ }^{1}$, Luciana de Fátima Barreto ${ }^{1}$, Monara Rochelle Cordeiro Marinho Cruz ${ }^{1}$, Francisco Gilberto Fernandes Pereira ${ }^{2}$, Andréa Lopes Barbosa ${ }^{3}$

Objective: to understand health education practices in the context of nursing education. Methods: a qualitative study held in a private Higher Education Institution. The participants were 22 subjects who answered a semistructured interview, whose information was organized and analyzed by the content analysis method. Results: three categories were identified: health education and the nurse as an educator; health education in primary care; and comparison of educational practices in levels of care. Conclusion: the students understood the importance of health education in their training, and felt the need to expand these practices to all health care levels.

Descriptors: Health Education; Students, Nursing; Education, Nursing.

Objetivo: compreender as práticas de educação em saúde no contexto da formação em enfermagem. Métodos: estudo qualitativo, realizado em Instituição de Ensino Superior da rede privada. Participaram 22 sujeitos, que responderam a uma entrevista semiestruturada, cujas informações foram organizadas e analisadas pelo método de Análise Conteúdo. Resultados: identificaram-se três categorias: educação em saúde e o enfermeiro como educador; educação em saúde na atenção primária; e comparativo das práticas educativas nos níveis de atenção. Conclusão: os acadêmicos compreenderam a importância da educação em saúde em sua formação, e sentiam a necessidade de expandir essas práticas para todos os níveis de atenção em saúde.

Descritores: Educação em Saúde; Estudantes de Enfermagem; Educação em Enfermagem.

${ }^{1}$ Centro Universitário Estácio do Ceará. Fortaleza, CE, Brazil.

${ }^{2}$ Universidade Federal do Piauí. Picos, PI, Brazil.

${ }^{3}$ Universidade Estadual do Ceará. Fortaleza, CE, Brazil.

Corresponding author: Sâmia Jucá Pinheiro

Rua Rafael Tobias, 1999, casa 23. Sapiranga. CEP: 60833-196. Fortaleza, CE, Brazil. E-mail: samia.enfa@hotmail.com 


\section{Introduction}

The Promotion health idea is closely linked to health education. It is a very contemporary theme, constituting the main element of New Public Health. In this sense, strategic actions of participation, education, training and popular autonomy in community health are involved, giving the population a review critically of their life, as well as their full access to information and rights in health ${ }^{(1)}$.

Health Education can be defined as a set of activities that influence the acquisition of knowledge, changes in attitudes, strengthening the social network organization, social control, and adoption of healthy behaviors, always for improving the quality of life and health $^{(2)}$.

Typically, Health Education is performed by interpersonal or impersonal advice. The interpersonal advice are conducted in offices, and schools in a more directly and close way to the individual, and the impersonal advice are those that occur using up the media to reach large numbers of people, both aimed at the same goal, which is to lead people knowledge about their health condition and how it can be influenced by internal or external factors ${ }^{(3)}$.

Health education practices from the idea that the individual learns to take care of his health, as well as prepare him to seek better living conditions, encourage him to make decisions and to exercise autonomy over his lives, should be directed to enable them to develop individual and collective activities of $\operatorname{care}^{(4)}$.

It is possible to identify grounded planning and implementation of Health Education practices usually in two paradigms: the Traditional or Preventive Model and the Radical Model. The Traditional Model relies on the idea of health as the absence of disease with educational strategies for biomedical assumptions. It is characterized by the full participation of health professionals as action executors aimed at preventing and minimizing health problems. Professionals should convince people to adopt compatible lifestyles, being the only options available to them. The Health Radical Model comes from the Health Promotion assumption that educational practices will aim to prevent diseases, and its focus is on the individual, though, considering that only disease prevention cannot be considered as a sufficient goal ${ }^{(5)}$.

The Health Education practice requires the health professional, especially nursing, for their proximity to this practice, a critical analysis of their performance, as well as a reflection of their role as an educator ${ }^{(3)}$.

One of the key roles of the nurse is the act of caring, and he is always seen as the caregiver. The act of caring has an important role in the daily life of health education practices as a guide for the prevention of damage and strengthens the nurse's relationship with the community they assist ${ }^{(6)}$.

The nurse plays an important role for the population since he participates in programs and health education activities aimed at improving the health of the individual, the family, and the general population. As an educator, the nurse is placed in the context that guides health education, since it is necessary to guide the people and show alternatives to take actions for their health in its broadest sense ${ }^{(3)}$.

Thus, the interest of the study arose from the need to understand the health education conceptions and educational health promotion practices in students' view of the undergraduate course in Nursing of one University Center, identifying how these practices can contribute to the training of future nurses as educators at different levels of health care.

The study is important because knowing that nursing professionals have considerable cooperation role in the teaching and learning of the population process, it is essential to identify the subjective impressions that students have regarding in this issue, since the time of university education can provide a field for greater assimilation of references that envisage a process strengthened by educational practices in health that cause the subjects to act autonomously in effecting social change and at the same time, develop 
autonomy, becoming multipliers of knowledge.

Thus, this study aimed to understand the health education practices in the context of nursing education.

\section{Methods}

This study is a qualitative research, because its focus is the depth, highlighting the characteristics and complexity of the phenomena, behaviors, and situations of the analysis of health education practices, according to nursing undergraduate students ${ }^{(7)}$.

The study was conducted in a private Higher Education Institution in the city of Fortaleza, Brazil, in May and June 2015.

As inclusion criteria, there were: be a Nursing student and attending the last semester of the undergraduate course, because in this period the students have experienced all the required stages, where they have had the opportunity to carry out educational strategies at all levels of health care. Participants should be enrolled in the course. A student who was not present at the time of data collection were excluded. Thus, the study subjects totaled 22 participants.

The subjects were approached randomly to participate in the research, by an invitation. At the time, the student received the consent and clarified form that contained all the information about the research to understand about the theme and take away their doubts about the study, confirming their participation by signing the form.

After signing the term, a semi-structured interview was conducted, consisting of three guiding questions, compiled especially for the research of individual character. They are 1 . What is the importance of health education achievement in the practice areas where the nurse is included as an educator? 2. By conducting health education in primary care, what is your greatest difficulty? 3 . What are the differences when performing health education at a tertiary and primary care level hospital?
The information acquired through the interviews were submitted to content analysis, which is a set of research techniques, based on three stages: pre-analysis, analytical description and inferential interpretation ${ }^{(8)}$. The material was organized in the pre-analysis phase, and the researchers transcribed the recorded speeches of the participants in full. Each participant received the name of AC, academic abbreviation, and the number corresponding to the data collection.In the analytical description, documents are analyzed deeply, based on the responses obtained in the collection and theoretical references. At this time, the subjects of the study were created, making a coding, classification, and/or categorization. In the reference interpretation, the relationships between the object of analysis and its wider context were established from the empirical data and information collected, reaching even the reflections to establish new paradigms in the structures and relationships studied $^{(8)}$.

The study complied with the formal requirements contained in the national and international regulatory standards of research involving human beings.

\section{Results}

The study was conducted with 22 students of the tenth semester, 14 females and eight males, with a mean age of 30 years old.

It was noticed that all academics who responded to the interview reported that health education achievement in the practice area is very important, because, through these actions, they could put into practice the knowledge acquired in lectures, and to view the role of the nurse as an educator and social responsibility.

The data were divided into three categories based on the responses obtained in the interview. They are Health Education and the nurse as an educator; Health education in primary care; Comparison of educational practices in levels of care. 


\section{Health education and the nurse as an educator}

There was the unanimous identification of the nurse as a educator health agent, able to promote individual and social transformations that promote healthy behaviors or to reduce damage against the illness. It was also found that the educational practices symbolize a time of double learning, both for students and for the patients, since the implementation of these activities provided familiarization with various themes and promoted the need for learning based on real problems. The speeches stressed the above: In my opinion, health education in stages is very important for learning and knowledge. When students do health education to patients, they learn more and stimulates the desire to help those in need, that is, the patient can leave the comfort zone and creates incentives to improve their health and quality of life (AC1). The importance of the nurse as an educator is high because he can advise on SUS policies, providing adequate guidance on treatments and disease, and also about the importance of health prevention (AC15). The nurse, since his formation, is already an educator. He is already formed to be an educator because health education is the basic pillar of health, bringing prevention as a means of education for the population (AC6).

It was also realized a scope on the topics addressed during the educational practices, demystifying the idea that health education is restricted to bodily biological situations of health and illness, but extrapolating to the actions of social control, rights and duties of patients and knowledge of public policy, revealing that the most effective model in their practices was the Radical Health, with assumptions based on health promotion and social determinants.

Still, in the context of health education and the nurse as an educator, it was found that health education is a tool for social transformation, which through educational practices can promote reflection, empowerment to improve the quality of life through disease prevention and health promotion.

\section{Health education in primary care}

The nurses who work in primary health care services are constantly faced with factors that hinder the achievement of educational practices. These barriers were also perceived by the students. According to the statements, there were problems in this task, characterized by a lack of interest, attention, and participation of patients, the building of a clear and accessible language that allows full access to health information, inappropriate environment for these practices, lack experience in designing innovative and fun activities and shyness. The reports demonstrate the above: The greatest difficulty found in health education has always been population support. The people never want to participate; then we arrive with a theme, and he thinks he already knows everything, little interest. We try to bring something attractive to see if they can get involved, but there is still many barriers between the teacher and the student (AC15). Draw public attention and get fixed their attention during the activity is the hardest part (AC20). The place is usually the waiting room, people are scattered, if you do not have the creativity or give a gift, the health education is ineffective (AC18). My biggest difficulty is to speak to the people like I have much trouble because I get nervous (AC8).

It was shown that the students faced various obstacles in developing some health education practices regarding the structure and the lack of physical and material resources, often hindering the care, the understanding and the pursuit of attention of the subjects. This can directly affect the outcome of the work done by the team.

Another difficulty presented by the students was the practices related to the lack of preparation of respondents who, most often, they feel shy or insecure to patient care. 


\section{Comparison of educational practices in levels of attention}

Despite the difficulties, it was observed that the students preferred the educational practices in health performed in primary care, as they are more encouraged in this context during the lectures, and also because they consider that the participation, attention, and people interest are best when compared with educational practices in the hospital network.

The deponents also showed that health education practices in primary care were aimed at disease prevention and health promotion, like those performed in the hospital were directed predominantly to reduce damage to health, clinical care to adapt to conditions treatment and training companions. The reports emphasize the above: ...In the primary level, you will focus more on health promotion activities and teach people how to prevent diseases to ensure improved quality of life (AC3). The difference is great because they are different strategies, different assistant, different people that require special attention. Outside the hospital, there are much simpler illnesses and the hospital has far more advanced and complex treatments performed, and the main difficulty is that (AC7). Moreover, in primary care, we have to score with the community and make the dissemination and ends up having more income; at the tertiary level, patients already debilitated more often, the emotional state is shaken, and we do not see results, that is, we have to prioritize health education in primary care (AC1). In primary care, there can be a dial and a choice of theme and the people to applied it; at the tertiary level, there are several levels of high complexity and lack of good state of consciousness of the patient making the educational activities being more geared to the caregivers (AC3).

Regarding the participation in educational practices, there was a preference for public primary care, because through the reports, it was apparent ease of gathering this audience for educational practices in which many said they had the option to schedule one day, local or even an appointment with the people, other than the tertiary level, where the patient is severe or weakened, hindering to carry out the activities.
In the tertiary care, the activities are geared towards healing and rehabilitation. According to the reality of this research, it was observed that the nursing students were not encouraged to do health education at the tertiary level.

\section{Discussion}

The results of the study corroborate the literature showing that the nurse as educator health agent, understanding that education is a tool for social transformation. From this perspective, the professions in the health area, especially nursing, can carry out educational activities within the service. Thus, nurses should guide the people about the most appropriate actions to be taken before the disease, since the lack of orientation of the population is a determining factor for non-adherence to treatment, and such information becomes essential to help them having a better quality of life ${ }^{(9)}$.

The study demonstrates the importance of educational practices in the process of training of health professionals. In the process of teaching and learning, there is the effort of everyone involved to reach the desired objective, which is configured in the transmission of knowledge. The teacher not only transmits the information to the learner, but he also acts as a facilitator of learning ${ }^{(10)}$.

Therefore, nurses can be considered a born educator in health, as he plays important roles in the education of the population through educational activities in health to guide them about the disease and its particularities around the prevention strategies, as well as the treatment options. In this approach, it can be said that the role of nursing is directly linked to an educational dimension ${ }^{(11)}$.

The results of the study also showed that the nurse is an educator since his formation because the construction of a nurse educator is essential for proper health care. It is clear that the health education practice has become an indispensable tool for the experience of the professional nurse, having his role 
in the care provided to patients and he is considered a practitioner agent of educational activities in health at all levels of care, using his extensive knowledge acquired during academic training ${ }^{(12)}$.

For nursing students from another study, health education has a specific goal: to help prevent disease and promote health, and to develop a sense of responsibility in people for their health and the health quality of the community he is inserted ${ }^{(6)}$.

The study results show that inexperience in preparing educational activities and shyness are considered barriers to this practice, signaling that students need more encouragement to carry out the educational practices. Teachers need to be more involved in this process by developing strategies that promote the importance of visibility of educational practices in care settings by students at any level of attention, showing that educational practice increases the pro-activity and taking the decisions of the future nurses ${ }^{(13)}$. Thus, through research conducted on health education from the perspective of the nursing student, it is suggested the subject of Health Education in educational institutions having a practical timetable for a better development of that competence, not limited to a highly theoretical subject ${ }^{(14)}$.

The Health Education transversality in nursing training curriculum promotes the development of the process of learning skills, encouraging students to know the professional reality and intervene when needed after a critical reflection. The course takes the academic professional to the experience professional practice, stimulating the development of autonomy, and improving communication skills for when professionals act in a more effective way ${ }^{(15)}$.

The relationship of the educational institution of professionals and health services improve the relationship of the learning process to create opportunities to experience and performance of academics in the health care network. Entering the student in the reality of workers enables the training of professionals prepared to work in the area ${ }^{(16)}$.

Another result of the study consistent with the literature is the lack of interest of patients in the educational practice. The lack of involvement of the public participating in educational activities in health is an important barrier to its performance since health education can be said to be an activity which is the exchange of knowledge and the reorientation of health practices. It is essential to the enhancement of dialogue stimulating the exchange of knowledge, emphasizing the idea that the professional is not the holder of knowledge and just population knowledge receipt $^{(17)}$.

Most of the time, the practices occur in an inopportune way and always allow inattention and distraction of patients. Thus, the development of educational activities in appropriate locations, noisefree, promotes adherence of the participants. More planned spaces provide opportunities for better addressing the problems ${ }^{(10,15)}$.

Primary Health Care policy is based on health actions for the promotion, disease prevention and their complications, treatment and also rehabilitation. Health professionals are committed to the promotion and quality of life of individuals. They also provide activities of educational practices involving the exchange of knowledge, building links with the population and development of the community participation process ${ }^{(18)}$.

The results of the study corroborate what the Ministry of Health of Brazil calls through the National Health Care Policy when they demonstrate the focus of educational practice in primary care and hospital network. It is understood that health education is present at all levels of care, in which educational activities are carried out in the primary care for disease prevention and health promotion, and tertiary educational practices are directed to the rehabilitation of the individual ${ }^{(5)}$. 


\section{Conclusion}

It was identified that the educational practices are important to nursing education, as configured in an exchange feature of mutual knowledge and professional growth. It is also understood that the practice together with theoretical knowledge base the health education activities, enabling to increase the academic experience, primarily responsible for the future process.

It was observed that the performance of educational practices is a challenge for all involved, as there are still many barriers related to the limitations of students to develop activities such as the ability to speak in public about issues related to health. It is believed that the described barriers are eased with the encouragement of creativity, interaction, and search for theoretical knowledge for future nurses.

Within the context of this study, it is necessary to reflect that training institutions, along with teachers, schedule actions aimed at stimulating health education practices, reorienting and enabling changes, developing skills, abilities and knowledge to the exercise of these practices not only in primary care, but at all health care levels, uniting knowledge and innovation to the process to achieve positive responses.

\section{Collaborations}

Pinheiro SJ, Lucas FEQ, Barreto LF and Cruz MRCM contributed to the study design, collection, analysis and interpretation of data, article writing and final approval of the version to be published. Pereira FGF and Barbosa AL contributed to writing the article and final approval of the version to be published.

\section{References}

1. Ferreira VF, Lopes MMB. Health education: challenges for an innovative practice. Rev Enferm UFPE on line [Internet]. 2013 [citado 2016 mar. 15]; 7(n. esp):5834-6. Disponível em: http:// www.revista.ufpe.br/revistaenfermagem/index. php/revista/article/view/4687/pdf_3567

2. Almeida ER, Moutinho CB, Leite MTS. A prática de educação em saúde na percepção dos usuários hipertensos e diabéticos. Saúde Debate. 2014; 38(101):328-37.

3. Cervera DPP, Parreira BDM, Goulart BF. Educação em saúde: percepção dos enfermeiros da atenção básica em Uberaba (MG). Ciênc Saúde Coletiva. 2011; 16(1):1547-54.

4. Dias GAR, Lopes MMB. Educação e saúde no cotidiano de enfermeiras da atenção primária. Rev Enferm UFSM. 2013; 3(3):449-60.

5. Colomé JS, Leidens CO. Educação em Saúde: por quem e para quem? A visão de estudantes de graduação em enfermagem. Texto Contexto Enferm. 2012; 21(1):177-84.

6. Oliveira RL, Santos MEA. Educação em saúde da família: conhecimentos e práticas do enfermeiro. Rev Enferm Integr Ipatinga. 2011; 4(2):13-9.

7. Richardson RJ. Pesquisa social: métodos e técnicas. São Paulo: Atlas; 2010.

8. Bardin L. Análise de conteúdo. São Paulo: Edições70; 2011.

9. Fernandes MCP, Backesl VMS. Educação em saúde: perspectivas de uma equipe da Estratégia Saúde da Família sob a óptica de Paulo Freire. Rev Bras Enferm. 2010; 63(4):567-73.

10. Sousa LB, Torres CA, Pinheiro PNC, Pinheiro AKB. Práticas de educação em saúde no Brasil: a atuação da enfermagem. Rev Enferm UERJ. 2010; 18(1):55-60. 
11. Costa GM, Figueredo RC, Ribeiro MS. A importância do enfermeiro junto ao PSE nas ações de educação em saúde em uma escola municipal de Gurupi. Rev Científica ITPAC [periódico na Internet]. 2013 [citado 2016 mar. 15]; 6(2). Disponível em: http://www.itpac.br/arquivos/Revista/62/6.pdf

12. Almeida AH, Soares AH. Health Education: Analysis of its teaching in undergraduate Nursing Courses. Rev Latino-Am Enfermagem. 2011; 19(3):614-21.

13. Gehlen MH, Ilha S, Walter RR, Grando MK, Colomé JS, Backes DS. Significados da prática educativa em unidades de desintoxicação química. Cogitare Enferm. 2013; 18(2):317-22.

14. Rosa RSD, Marciano LCV, Rocha FES. Educação para a saúde na ótica do acadêmico de enfermagem. Rev Min Enf. 2007; 11(2):181-7.
15. Pereira FGF, Caetano JA, Moreira JF, Ataíde MBC. Práticas educativas em saúde na formação de acadêmicos de enfermagem. Cogitare Enferm. 2015; 20(2):332-7.

16. Vendruscolo C, Kleba ME, Krauzer IM, Hillesheim A. Planejamento situacional na estratégia saúde da família: Atividade de integração ensino-serviço na enfermagem. Rev Gaúcha Enferm. 2010; 31(1):183-6.

17. Oliveira MR, Leonel ARA, Montezeli JH, Gastaldi $\mathrm{AB}$, Martins EAP, Galvão C. Conception of undergraduate nursing students on the practice of health education on first aid. Rev Rene. 2015; 16(2):150-8.

18. Ministério da Saúde (BR). Política Nacional de Atenção Básica. Brasília: Ministério da Saúde; 2012. 